DOI 10.4467/2543733XSSB.21.011.13804

REDŽEP ŠKRIJELJ

State University Novi Pazar

\title{
THE IMPACT OF DEMOCRATIC CHANGES IN POLAND UPON THE POLITICAL TRANSFORMATION AND BREAKUP OF THE SOCIALIST FEDERAL REPUBLIC OF YUGOSLAVIA
}

\begin{abstract}
Summary
The fall of the deeply rooted communism in the countries of the Eastern Bloc in the 1980s has differed according to the level of achieved rights and freedoms, especially in Poland, as it was finalized with the breakup of the Soviet Union. The changes announced with the foundation of "Solidarity" - the first independent syndicate - which spread to the factories and enterprises across Poland beginning in the Lenin Shipyard. The staunch national pride and freedoms, empowered with the strength of the Catholic Church effectively eliminated the weak Soviet-imposed communism. The foundation of the first independent and free Polish syndicate in the strong Soviet Bloc catalyzed the initiation of abrupt and serious reforms in the countries of the Eastern Bloc. The fall of the Berlin Wall intensified the initiated processes of reintegration and independence from external political torture and poverty. The initiated processes intensified amplified changes in SFR Yugoslavia even though the breakup of this country in the early 1990s cost more than its establishment.
\end{abstract}

Key words: real communism, breakup, Eastern European Bloc, Soviet Union, Poland, Yugoslavia

\section{Introduction}

It is very difficult to claim or answer the question if the democratic revolutions in Eastern Europe had a direct influence upon the stratification of SFR Yugoslavia, because the roots of its gradual dissolution reached out to the distant past, and were a direct consequence of the omissions and disputes dating from the period of the formation of the socialist system. 
The rule of Josip Broz Tito (1892-1980), introduced a "new definition of socialism: industrialization, high-standard, social justice, and perspective". The death of the former president brought an end to the strategically wise policy of equidistance towards both global military alliances, which brought Yugoslavia a huge international reputation that was disproportionate to the size and objective importance of the country ${ }^{2}$. In the late eighties, SFR Yugoslavia, as a multinational socialist state, gradually disappeared from the map of the European map together with the USSR and Czechoslovakia. Their downfall marked the triumph of capitalism over the socialist world.

The loss of distinct national sovereignty by the countries of the Eastern Bloc became a painful trauma. The lightly more convenient spirit was felt in the countries of Eastern Orthodox tradition, in which, despite the nature of the historical relations and traditional proximity, the Soviet Perestroika conditioned the fall of dictator regimes in a manner of a domino-effect.

It is quite certain that, in addition to the Perestroika of Mikhail Gorbachev, the strongest influence upon the strengthening and success of the democratic-reform revolution was made by Polish "Solidarity". This movement capitalized on the weak spots of a very uncertain regime which found itself under the pressure by citizen syndicates, the intellectual public, and the Catholic Church for long years and which, as early as the 1980s, showed serious signs of weakening amidst apparent economic stagnation.

The Polish society which was qualitatively different and essentially homogenous from the aspect of political structure managed to significantly limit the absolute domination of the state-party apparatus in $1981^{3}$. Yugoslav politicians marked the crisis in Poland with criticism, which was especially visible between 1981 and 1983. At a meeting of the Central Committee of the League of Communists of Yugoslavia, there was a proposal to limit the size of news articles dealing with the crisis in Poland ${ }^{4}$.

The Yugoslav public very actively observed the long negotiations and agreement between the "Solidarity" syndicate led by Lech Wałęsa's and the pressured Polish government which agreed to multi-party elections ${ }^{5}$. On June $4^{\text {th }}, 1989$, Poland abolished the old regime and convincingly elected the "Solidarity" list, while on the other side of the world, a bloody confrontation at student-organized protests took place on Beijing's Tiananmen Square ${ }^{6}$. The efforts by Polish communists to regain momentum and exacerbate the prosperity of the government of Tadeusz Mazowiecki and the "Solidarity" movement by giving concessions to Moscow, were met by resignation in the southeastern European countries, espe-

\footnotetext{
${ }^{1}$ Slavko Milosavlevski, Kontradikcije Josipa Broza, Kiz - 'Dositej’ - Beograd 1990, p. 120.

${ }^{2}$ Todor Đ. Kuljić, Tito - sociološko-istorijska studija, Beograd: Institut za političke studije, Beograd 1998: pp. 229-230.

${ }^{3}$ Zagorka Golubović, Istorijske pouke socijalističkog pokreta u Poljskoj, Revija za sociologiju, Vol. XI (1981), No. 1-2, Beograd 1980-1981, p. 47.

${ }^{4}$ Nebojša Stambolija, Odnos jugoslovenske javnosti prema ratnom stanju u Poljskoj 1981-1983, [in:] Polska i Jugostawia w stosunkach międzynarodowych po II wojnie światowej, relacje wielostronne i wielopoziomowe, ed. Momčilo Pavlovicia, Andrzeja Zaćmińskiego, Bydgoszcz 2014, p. 182.

${ }^{5}$ Slobodanka Ast, Poljski sindikat 1980-2005: Solidarnost i melanholija, Vreme br. 765, Beograd, 1.9.2005, https://www.vreme.com/cms/view.php?id=426530.

${ }^{6}$ The massacre at the Beijing Tiananmen Square occurred when Solidarity gained a major victory at the elections on June $4^{\text {th }} 1989$. (Naomi Klein, Doktrina šoka: uspon kapitalizma katastrofe. Zagreb: V.B.Z., 2008, p. 189).
} 
cially among the Yugoslav public, which impatiently observed the process of changes ${ }^{7}$. Facing the realities of life, a ruined economy, and a large wave of economic migration which was slowed down by the visa-barrier, presented a new temptation for "Solidarity" This was followed by a drastic devaluation of the national monetary unit, poverty, and shortage, so the "Solidarity" government was forced to open and liberalize the market, introduce subventions and liquidate non-rentable enterprises. The lack of convertible money slowed down the liberalization and increased unemployment which meant a drop in popularity of the "Solidarity" movement. The dramatic elimination of the old economic model brought success to Poland and increased its democratic potentials ${ }^{9}$. Poland performed a successful transition and change of the political system despite being a country of the former Eastern Bloc. The turnover after 1989 enabled the building of a democratic judicial state and respect of basic human freedoms ${ }^{10}$.

Such a course of political events could not remain unechoed in the Democratic Republic of Germany, Czechoslovakia, Hungary, Romania, and Bulgaria.

Hungary, a country closest to break away from communism and initiate reforms, was seeking to abolish Soviet dictatorship and tried to activate new economic mechanisms in this country of ruined economy, aiming to transit from a single-party system into a parliamentary democracy. Besides "relaxing" the borders with its neighbors (e.g. Austria), which provided the escape of thousands of East German "tourists", it began receiving foreign investments which accelerated new internal and foreign policies as a platform for the strengthening of the democratic potentials of the country. The breakup with communism had to be conducted differently in Poland's neighboring countries such as East Germany and Czechoslovakia. The approval of Erich Honecker to withdraw and the demolition of the Berlin Wall (November $9^{\text {th }}, 1989$ ) brought relief and the first free elections were held on March $18^{\text {th }}, 1990^{11}$. The triumph of the Christian Democratic Union (CDU) created conditions for unification between East and West Germany.

The further disintegration of the Soviet domination in Eastern Europe was continued in Czechoslovakia (November 1989) which represented an orthodox communist bulwark. Following the Velvet Revolution in December 1989, conducted in the spirit of Czech enlightenment and democracy, playwright Vaclav Havel became the new president, as he later became one of the key players in the peaceful disintegration of Czechoslovakia.

The transitional courses in Eastern Orthodox countries were developing considerably slower (Bulgaria), violently (Romania), and militarily (SFR Yugoslavia). The participation of a small opposition bloc enabled the triumph of the Socialist Party at the elections held in November 1990 in Bulgaria.

\footnotetext{
${ }^{7}$ Adam Michnik, Wasz Prezydent, Nasz Premier, Gazeta Wyborcza nr 40, 03/07/1989, p. 1.

${ }^{8}$ Edmund Vnuk-Lipiński, Teorijska zapažanja o procesu transformacije u Poljskoj, Republika, God. XV, br. 1-31. jul 2003, p. 312-313.

${ }^{9}$ David Ost, The Defeat of Solidarity: Anger and Politics in Post-communist Europe. Ithaca, N.Y.: Cornell University Press, 2005, pp. 33-35.

${ }^{10}$ Marko Babić, Aksiologija i promjene - Slučaj Poljske, Godišnjak fakulteta političkih nauka u Beogradu, I deo: Politička teorija, politička sociologija, politički sistem, Br. 78, V. Beograd, 5, Jun 2011, p. 67.

${ }^{11}$ Klaudija Kroford, 1989. - Godina preokreta ne samo za Nemce, Zbornik: Konsolidacija demokratije 20 godina nakon pada Berlinskog zida (Red.: Ilija Vujačić, Čedomir Čupić i Bojan Vranić). Fakultet političkih nauka \& Konrad Adenauer Schtiftung, Beograd 2009, p. 8.
} 
The dictatorship in Romania was ended with a coup and the forcible ousting of the Nicolae and Elena Ceauşescu couple, bringing an end to totalitarianism and repression, thus enabling the victory (in May 1990) of the National Front led by Ion Iliescu, whose reign resembled the old regime.

The fall of communism in the isolated country Albania, which remained outside Soviet influence, has been the last to take place in Europe. The student protests in Tirana (December 1990) and other cities led to the establishment of democratic pluralism and the triumph (March 1992) of the Democratic Party of Albania (PDSH). The chairman of the Democratic Party Dr. Sali Berisha was elected the first non-communist president by the Albanian parliament on 9 April $1992^{12}$.

The introduction of democratic changes in Poland (1989), lead to a gradual abolishment of communist rule in the countries of the Soviet socialist bloc, thus initiating the process of unification of the democratic potentials of a new era in Europe. The rise of the revolutionary climate in Poland would preliminarily influence the restoration of democratic capacities of Eastern European countries which further developed with variable intensity.

\section{The influence of democratic changes in Poland and the countries of the Soviet Bloc upon the political situation in SFR Yugoslavia}

The result of the two-week-long worker strike in the Lenin Shipyard ${ }^{13}$ in Gdańsk, which spread to factories and enterprises throughout the entire country, as well as the finalization of negotiations with the government on August $31^{\text {st }}$, 1980, marked the beginning of a new era of democracy in Europe thus feeding the tendencies of Poles and peoples of other European communist states in the Soviet Bloc to overthrow communism.

Judging by the development of the situation in Poland, Wałęsa's "Solidarity" which had more than ten million members represented a great national movement in the eyes of Yugoslav and the European public ${ }^{14}$. Almost overnight, the movement transformed into a great people's uprising which created strong interconnectedness between workers, intellectuals, peasants, priests, students, and regular citizens, accomplishing the dream of a union between the oppressed and disgruntled workers against the communist Soviet empire in a most harmonious way.

A part of the Yugoslav public was impressed by the Polish movement and the "idealistic and practical engagement of its participants in creating a new type of social movement on a novel basis. It encouraged the same treatment of the engagement of the worker and the engagement of a professor or a student because all of them were linked with participation in action and thinking about their mutual motives and aims of the movement. This was a unique quality of this very massive movement" $"$. The foundation of »Solidarnośc «, and the proclamation of "Message to the Nations of Eastern Europe" adopted by the Congress

\footnotetext{
${ }^{12}$ Elez Biberaj, Shqipëria në tranzicion, Rruga e vështirë drejtë demokracisë 1990-2010, AIIS, Tiranë, 2011, p. 205.

${ }^{13}$ Colin Barker, Revolutionary Rehearsals. London: Bookmarks, 1987, pp. 170-171.

${ }^{14}$ Andrzej Paczkowski, Pola stoljeća povijesti Poljske: 1939.-1989. godine. Profil, Zagreb 2001, pp. $452-456$.

${ }^{15}$ Zagorka Golubović, Istorijske pouke socijalističkog pokreta u Poljskoj..., p. 54.
} 
of Solidarity on September $8^{\text {th }}, 1981^{16}$ in which the syndicates from the countries of the Eastern Bloc were called to join the struggle for the freedom of assembly, brought an insight towards new perspectives for true emancipation of the society and freedom from all forms of domination of the state, in a form of an "alternative society", surpassing the previous reformist and revolutionary projects ${ }^{17}$.

The struggle for political and human freedoms profiled the moral and intellectual purity of the movement in one of the most populous former Soviet satellite states, which would very soon become a serious example of a democratic transition as an exhibit of capitalism $^{18}$. In the late 1980s and early 1990s, the Yugoslav public considered Poland as a country of a growing economy marked designated by experts to be an economic miracle.

\section{Political democracy and the dissolution of SFR Yugoslavia}

The beginning of the last decade of the $20^{\text {th }}$ century marked the second disappearance of Yugoslavia ${ }^{19}$. Aggregated antagonisms and the tendency for national homogenization of certain members of the loose federation, especially Serbia, provoked conflicts of unexpected proportions. The years of great changes in the countries of the pro-Soviet Eastern European Socialist Bloc, especially in Poland, increased the fears of "Lebanonization"20 of Federal Yugoslavia which became geopolitically weakened.

The breakup of the ruling League of Communists at the XIV Extraordinary Congress in Belgrade in January 1990 announced the dissolution of the SFRY, which was later confirmed at the first multi-party elections held in six federal republics and two autonomous provinces $^{21}$. The rise of all-Serbian political and military hegemony together with the multinational discord led to the triumph of nationally oriented parties, which abandoned the half-century-long struggle to build a Yugoslav identity that, as a supranational phenomenon, waned in Slovenia, Croatia, and Serbia. This came to fruition in the first multi-party elections in the federal units during 1990, alongside the victory of national parties whose programmatic conception did not guarantee the survival of the common state.

${ }^{16}$ Marek Kozłowski, Bogusław Śliwa (1944-1989) - działacz opozycji demokratycznej i „, Solidarności”, w Kaliszu. Szkic do portretu; [in:] Krzysztof Brzechczyn (red.), ,Solidarnośc” 1980-1981 w kraju i w Wielkopolsce. Szkice do portretu (Studia i Materiały Poznańskiego IPN, t. XXXV). Instytut Pamięci Narodowej, Poznań 2016, p. 207.

${ }^{17}$ Zagorka Golubović, Istorijske pouke socijalističkog pokreta u Poljskoj..., p. 55.

${ }^{18}$ Goran Musić, Suprotstavljene interpretacije tranzicije, [in:]: Balkan i Srednja Evropa - Izgubljeno u tranziciji: Kritička analiza procesa društvene transformacije, Rosa Luxemburg Stiftung, Beograd 2011, pp. 88-89.

${ }^{19}$ First Yugoslavia was created following WWI, with the spreading of the idea of cultural kinship and necessities for a unity of Southern Slavs, formerly known as the Kingdom of Serbs, Croats, and Slovenes, and later as the Kingdom of Yugoslavia (1929-1941). It was re-established on November 29th, 1943, as a federation of six republics and two autonomous provinces. After a gradual dissolution beginning with the separation of Slovenia and Croatia in 1991, it survived until 2006. The process of the disintegration of the socialist Yugoslavia was continued with the bloody war in Bosnia and Herzegovina (1992-1995).

${ }^{20}$ Nikola Samardžić, Drugi dvadeseti vek, Službeni glasnik, Beograd 2008, p. 12.

${ }^{21}$ By hurried and illegal constitutional changes (29.3.1990) Serbia limited the autonomy of Kosovo which confirmed the decades-long practice of torture, pressure, and intolerance towards the communities of minorities. 
The mollification of the Cold War euphoria contributed to the stumbling of the Non-Aligned Movement in which Yugoslavia, as one of its founding countries, ceased to be a leading factor. The rising re-Sovietization of Yugoslav foreign politics increased the activities of Croatian and Serbian nationalists leading to the aggravation of the enduring crises. The problems which exacerbated the economic-productive capacities of Poland, pressured Yugoslavia too, as the galloping inflation and the external debt to the International Monetary Fond of more than $\$ 20$ billion, as well as the decline of the gross domestic product also occurred here ${ }^{22}$. Nevertheless, the reforms became meaningful only in the late 1980s, but they were enforced with difficulties due to the inflamed national antagonisms. With its position in the Balkans, Yugoslavia was important for the interests of the US, but it became clear that after the end of the Cold War and the liberalization of Eastern Europe, it lost its former geopolitical significance, as expectations were rising that it would, like Poland, the Czechoslovak Republic, and Hungary, transform and orient itself towards a market economy, respectful of human rights ${ }^{23}$. An unsolvable problem for the government, embodied in the federal assembly represented by old-fashioned communists who transformed into fierce nationalists opposing the liberalization of social relations. The appointment of the progressive reformist Ante Marković ${ }^{24}$ as a Federal Prime Minister ${ }^{25}$ increased $^{2}$ optimism for new reforms that were halted by the disintegrative elements in the Yugoslav society which showed an inability to reform the stumbling socialist organization. Monetary reforms were initiated at the beginning of 1990 as the Yugoslav Dinar was made convertible and announced the opening of the market, labor, stock, and capital, the establishment of mixed domestic and foreign companies, a decrease of tax rates which resulted in the complete diminishment of the inflation by summer ${ }^{26}$.

${ }^{22}$ Branko Petranović, Istorija Jugoslavije 1918-1988, t. III „Socijalistička Jugoslavija 1945-1988”, Nolit, Beograd 1988, pp. 444-447.

${ }^{23}$ Voren Zimerman, Poreklo jedne katastrofe. Jugoslavija i njeni rušitelji (Beograd: Dan Graf, 1996), pp. 4-5.

${ }^{24}$ The last Prime Minister of SFR Yugoslavia, who engaged young Jeffrey Sachs as an advisor during the implementation of his anti-inflation program. Promoting internal convertibility of Dinar, freezing wages, and controlling infrastructural economic fields - he succeeded in stopping hyperinflation that reached an annual rate of $2700 \%$. Sachs was also an advisor in the government of Polish Prime Minister Tadeusz Mazowiecki. It is considered that transition to a capitalist economy became successful only when Sachs directives were abolished and Leszek Balcerowicz became Minister of Finances. (Dimitrije Boarov, Džefri Saks, [in:] Vreme, no. 581, 21.2.2002)

${ }^{25}$ Ante Marković (1924-2011), was the last president of the "Federal Executive Council" and the founder of the "Union of Reform Forces of Yugoslavia" in 1990. He was the countries prime minister between March $16^{\text {th }}, 1989$, and December $19^{\text {th }}, 1991$. At the press conference, since there was no institution to which he could consign his resignation, "he surrendered his mandate to the citizens of Yugoslavia".

(Ante Marković, Hrvatska Enciklopedija, mrežno izdanje. Leksikografski Zavod Miroslav Krleža, 2020, Pristup. 24.4.2020. <http://www.enciklopedija.hr/Natuknica.aspx?ID=39021>.)

${ }^{26}$ On June $29^{\text {th }}, 1990$, at a joint meeting of the Federal Council and the Council of Republics and Provinces of the SFRY Assembly, Ante Marković expounded the „Economic Reform Program”, outlining his view of the FRY's triumph over the crisis, and the development of ,a new economically efficient democratic, socially just, humane and open society", informing the people present that foreign exchange reserves have increased by $\$ 3$ billion and external debt was reduced to the now incredible $\$ 2$ billion since June 1988. (Savezno izvršno veće - Sekretarijat za informacije (1990). Program daljih reformi jugoslovenskog društva-vreme promena). Beograd, pp. $7-12$. 
One of the greatest disintegrative factors which halted further reforms was the Kosovo Crisis which began as a local problem that ultimately developed into a general Yugoslav problem. The military and police repression by Serbia ${ }^{27}$, as well as the manipulation with the fear of the endangeredness of the local Serbian populace paved the way for the rise to the political scene for Serbian nationalists, former dissidents from the state security service and certain notorious church officials.

The culmination of interethnic antagonisms was caused by the SAAS (Serb.: SANU) ${ }^{28}$ Memorandum (published in 1986) which proclaimed the "all Serbs in one state" thesis and which caused concern among the non-Serbian population in Yugoslavia, especially in Bosnia and Herzegovina, Croatia, Montenegro, and other federal units. The purge inside the party ranks against rebellious individuals begun on Kosovo. The strike of the Albanian miners in the Trepča mine ${ }^{29}$, who protested carrying the picture of the creator of communist SFR Yugoslavia, Josip Broz Tito, somewhat resembled the protests and demonstrations in Poland and other Central European communist countries.

Soon followed the dispute with Slovenia and Croatia, which was used by Croatian and Serbian nationalists to bring back memories of the Ustaše crimes and genocide against Serbs, Jews, Roma, and others. In the Republic of Slovenia, President of the League of Communists of Slovenia Milan Kučan ${ }^{30}$ encouraged freedom of expression and discussion on vital questions. The arresting of the "Mladina" journalist and former military officer Janez Janša by the members of the Yugoslav People's Army indicated that the state-party leadership was planning to conduct a military coup in Slovenia ${ }^{31}$. At the great meeting in Ljubljana on February 27th, 1989, Kučan appealed that the human rights of Albanians in Kosovo have to be respected ${ }^{32}$. Subsequent demonstrations in Belgrade were finalized with the arrest of Albanian communist leader Azem Vllasi ${ }^{33}$. At the end of March that year Serbia changed its constitution by limiting the rights and freedoms of Albanians who responded with abandoning the Serbian educational system ${ }^{34}$.

${ }^{27}$ Noel Malkolm, Kosovo - Kratka povijest, Dani, Sarajevo 2000, p. 176.

${ }^{28}$ The document was composed in April 1986, by the Serbian Academy of Arts and Sciences. It was a strategic program of the Serbian intelligence through which the resolution of the Serbian question in SFR Yugoslavia was attempted. By its provisions, the Memorandum does not recede from the expansionist program Načertanije (1844) which was authored by Ilija Garašanin, or the political program of the Chetnik ideologue Stevan Moljević from 1941

${ }^{29}$ Branko Podgornik, Protest pod zemljom, Vjesnik, Zagreb, 21.02.1989, p. 14.

${ }^{30} \mathrm{He}$ was elected the President of Slovenia after this country gained independence in 1991. As an independent candidate, he served on this position in two terms (December $6^{\text {th }}, 1992-$ November $22^{\text {nd }}, 1997$ and November 23 ${ }^{\text {rd }}, 1997$ - December 22 ${ }^{\text {nd }}, 2002$ ); http://www.bivsi-predsednik.si/up-rs/2002-2007/bp-mk.nsf/ostalo/biografija.

${ }^{31}$ Lidija K. Radojević i Ana Podvršič, Slovenačka omladina i neoliberalizacija Jugoslavije: od alternativnih pokreta do liberalnog trećeg bloka, [in:] Gradove smo vam podigli: o protivrečnostima jugoslovenskog socijalizma, Centar CZKD - Centar za kulturnu dekontaminaciju, Beograd 2018, p. 99 (pp. 89-105).

${ }^{32}$ Radina Vučetić, Vreme kada je narod govorio; [in:] Dokumenti o prošlosti: Politika, 1988-1991. (Odjeci i reagovanja - Okrugli sto), Fond za humanitarno pravo, Beograd, 14-15. decembar 2001, 13; Laura Silber i Allan Little, Smrt Jugoslavije, Co Libri, Rijeka - Opatija 1996, p. 69.

${ }^{33}$ The arrest was finagled on the meeting in front of the Federal Assembly in Belgrade, on February $28^{\text {th }}$, 1989 by a mass of 600 thousand people. The Serbian leader Slobodan Milošević executed the announced arrest of Azem Vllasi, three days after the meeting (Vodič za unutrašnji dijalog - Kosovska hronologija 1974-2017. Beograd, Septembar 2017, 8)

${ }^{34}$ Ibidem, p. 10. 
The breakup of SFR Yugoslavia was confirmed by the disagreement of the representatives of Slovenia and Croatia at the XIV Congress of the League of Communists (20 to 23 January 1990) of Yugoslavia in Belgrade as they asked for greater independence ${ }^{35}$. The erosion of the League, which represented one of the integrative factors of Yugoslavia, brought changes in the Yugoslav People's Army (YPA), as its reorganization was made with a purpose of achieving the project of Greater Serbia transforming it from Yugoslav into a Serbian army ${ }^{36}$. Eventually, the disbandment of this Congress marked the gradual disappearance of Yugoslavia as a state and political whole.

The tendencies of Slovenia and Croatia towards European integration were opposite to the wishes of Serbia to turn to communism and nationalism. Croatia held a referendum on May 19th, 1991, on which 93,2\% of the voters opted for independent Croatia. The Serbian president Milošević was trying to gain the public opinion on his side by prolonging and emphasizing the situation of the Serbian minority in Croatia ${ }^{37}$ through pressure over Slovenia and Croatia.

The Serbian minority in Croatia, aided by the YPA forces ${ }^{38}$, organized an armed rebellion and proclaimed autonomy ${ }^{39}$. The election of Slobodan Milošević as the president of Serbia on December $23^{\text {rd }}, 1990^{40}$ led to another exacerbation of the political relations which culminated in the March 9 Protests which were pacified with military vehicles being sent against the gathered citizens and the arrest of the protest leader Vuk Drašković ${ }^{41}$.

The general situation was additionally worsened with the request of the pro-Serbian military leadership which asked the Presidency of SFR Yugoslavia to declare a state of emergency. Realizing that the military sided with the Serbian national interests, the members of the Federal Presidency (Stipe Mesić, Janez Drnovšek, Vasil Tupurkovski, and the Bosnian member Bogić Bogićević) voted against the proposal for martial law.

Further developments were favorable for Croatia and Slovenia, which declared independence on June $25^{\text {th }}$, 1991 . The invasion of the military and police forces of YPA in

\footnotetext{
${ }^{35}$ The leader of Slovenian communists, Milan Kučan, emphasized that SR Slovenia is a sovereign state of the Slovenian people as it does not accept the unitary and centralist organization of the Federation. The Congress was brought into question as the delegation from Slovenia decided to abandon it. (Dejan Jović, Jugoslavija država koja je odumrla, Prometej, Zagreb 2003, p. 477; Davor Pauković, Posljednji kongres Saveza komunista Jugoslavije: uzroci, tijek i posljedice raspada, Suvremene TEME - CONTEMPORARY issues, Vol. 1, No. 1, Political Science Research Centre, Zagreb 2008, p. 27).

${ }^{36}$ Senija Milišić, Genocid: Pripreme i poricanje. Uvod u realizovanje genocida i zatvaranje kruga genocida, Ljudska prava, 1-4, Sarajevo 2008, pp. 216-217.

${ }^{37}$ On September $30^{\text {th }} 1990$, in accordance with the results of the autonomy referendum $(19.8-2.9 .1990)$ held in Croatian municipalities in which Serbs represented a majority or were significantly numerous, the Serbian National Council declared autonomy of the Serbian people in Croatia. (Republika Hrvatska i Domovinski rat 1990.-1995. Dokumenti - Dokumenti institucija pobunjenih Srba u Republici Hrvatskoj (1990-1991), knj. 2, (edit. Mate RUPIĆ), Hrvatski memorijalno-dokumentacijski centar Domovinskog rata, Dokumenti, knj. 2, Izvješće Centralne komisije o provođenju izjašnjavanja u Jugoslaviji o autonomiji srpskog naroda u Republici Hrvatskoj, 30.9.1990; Dokumenti, knj. 2, Srpsko nacionalno vijeće proglašava autonomiju srpskog naroda u Hrvatskoj, 30.9.1990., Slavonski Brod 2007, p. 83, 85).

${ }^{38}$ Nikica Barić, Srpska pobuna u Hrvatskoj: 1990.-1995. Zagreb: Golden marketing - Tehnička knjiga, 2005 , p. 121. Barić wrote about the „open support of the Yugoslav Peoples Army to the rebels”...

${ }^{39}$ Dokumenti, knj. 2, Srpsko nacionalno vijeće proglašava autonomiju srpskog naroda u Hrvatskoj, 30.9.1990, p. 85 .

${ }^{40}$ Nikola Samardžić, Drugi dvadeseti vek..., p. 148.

${ }^{41}$ M. Vasić, S. Cerović, A. Ćirić i dr., Krvava odbrana vlasti, Vreme, Beograd 11.3.1991, pp. 10-14.
} 
Slovenia resulted in the Ten-Day War in which the main casualties were among young Yugoslav soldiers and civilians ${ }^{42}$.

On July $7^{\text {th }}, 1991$ in Brijuni, by efforts of the Yugoslav leadership and three representatives of the European Community, a joint declaration on the peaceful resolution of the Yugoslav crisis was adopted, providing a ceasefire in Slovenia, as well as the withdrawal of the Yugoslav People's Army and the continuation of negotiations on the future of Yugoslavia, based on the principles of the Helsinki Final Act and the Charter of Paris for a New Europe $^{43}$. Gradual failure of the negotiations led to violent outbreaks of armed conflict in Croatia even before the expiration of the three-month moratorium.

In contrast to Slovenia and especially Croatia, Macedonia peacefully seceded from Yugoslavia, without the opposition of state institutions. The Declaration of Independence was adopted by the Sobranie (English: Assembly) on January $25^{\text {th }}, 1991$. This was a constitutional act that defined that Macedonia would remain a part of Yugoslavia if all other republics decided the same, but in case they disassociate, Macedonia would follow their example. On a referendum held on September $8^{\text {th }}, 1991$, its citizens voted for independence from Yugoslavia ${ }^{44}$, and this decision was not opposed by Belgrade ${ }^{45}$. Subsequently, $500 \mathrm{UN}$ soldiers were allocated on the new countries border with the remnants of Yugoslavia ${ }^{46}$.

On August 27 $7^{\text {th }}, 1991$ in Brussels, the Council of the European Union decided to convoke the "Conference for Yugoslavia" as a constant form of European mediation in the Yugoslav crisis. An arbitration body of experts for the consideration of constitutional-state questions called the Badinter Arbitration Committee was formed. The Declaration on Yugoslavia was the first act of the Conference mediated by the British diplomat, Lord Peter Carrington, by which belligerents in Croatia were called to end the war, and that the borders imposed forcefully, without an agreement, will not be recognized and human rights must be respected ${ }^{47}$. Milošević's further policy after the secession of Slovenia was the

\footnotetext{
${ }^{42}$ Slovenia and Croatia had a precise and publicly announced military-political goal: statehood and national sovereignty; the peoples of these two republics had undergone previous national homogenization to a degree of fanaticism and readiness to make sacrifices for national goals around which they gained strong international allies. (Rat u Sloveniji - Dokumenta Predsedništva SFRJ 1991, tom II (jun - jul 1991), (redaction: Kosta Nikolić, Vladimir Petrović), Institut za savremenu istoriju \& Fond za humanitarno pravo, Beograd 2012, p. 41).

${ }^{43}$ The Brioni Declaration was based on the Declaration of the EC on June $5^{\text {th }}, 1991$ and the proposals of the $\mathrm{EC}$ on June $30^{\text {th }}$, 1991, about a ceasefire and beginning of negotiations about the future of Yugoslavia. (Ibid. pp. 71-75)

${ }^{44}$ Služben vesnik na Rep. Makedonija, 43/1991, Skoplje, 1991.

The secession was a result of a referendum on which $95.26 \%$ of the voters agreed for the statehood and sovereignty of Macedonia confirmed by the Declaration adopted in the Macedonian Sobranie.

${ }^{45}$ After gaining independence, Macedonia became a member of the United Nations on April 8th, 1993, under the temporary name the Former Yugoslav Republic of Macedonia (due to a naming dispute with Greece). Following the Prespa agreement on June 17th, 2018, the Macedonian naming dispute was solved. Greece provided opposition to the constitutional name of Macedonia, so the latter had to join the United Nations under the temporary designation of the Former Yugoslav Republic of Macedonia. The Macedonian parliament decided on October 19th, 2018 to initiate constitutional reforms that were finalized on January 11th, 2019. It became effective on February 12, 2019, when the Greek parliament ratified the Prespa agreement and the protocol of NATO membership for North Macedonia.

${ }^{46}$ Nikola Samardžić, Drugi dvadeseti vek..., p. 149.

${ }^{47}$ A , Proposal for the Reorganization of Yugoslavia” was drafted on September $7^{\text {th }}, 1991$, at the Conference in Den Haag. It was not accepted by the federal units, after which, on November $8^{\text {th }}$, the mediating mission of
} 
disintegration of Croatia ,which had to serve for the strengthening of national unity and the realization of populist promises" ${ }^{\prime 4}$. The Croatian War of Independence was initiated with the assistance of the Montenegrin government which allowed the attack on Dubrovnik ${ }^{49}$ and assisted in the Battle of Vukovar ${ }^{50}$. Following the heavy shelling and destruction of large portions of Croatia, one-third of this country was under the control of Krajina Serbs and the YPA.

The war in Croatia intensified the crisis in Bosnia and Herzegovina and contributed to the internationalization of the Yugoslav crisis. Apart from being passively worried, the international community did not stop the conflict. The fact that every federal unit had its minorities in other republics caused the legislation of embargo on the export of arms to Yugoslavia, as well as the allocation of UNPROFOR units ${ }^{51}$.

At the end of bloody 1991, the idea of reintegration of Yugoslavia was abandoned. One of the ways to exit the Yugoslav crisis was the recognition of the independence of Slovenia and Croatia by the European Economic Community, which delivered a serious political blow to Milošević's policies.

With the formation of the Federal Republic of Yugoslavia on April $27^{\text {th }}, 1992$ by Serbia and Montenegro, Serbs from Croatia and Bosnia and Herzegovina, who by a plebiscite decided to remain in truncated Yugoslavia, were left outside the new countries borders. A secret deal was reached between Serbian president Milošević and Croatian president Franjo Tuđman for the division of the territories of Bosnia and Herzegovina. The proclamation of Croatian territorial communities in Bosnia and Herzegovina, especially in Herzeg-Bosnia, accelerated the organization of the independence referendum of Bosnia and Herzegovina between 29 February and March 1st, $1992^{52}$. Based on the referendum results, the European Community recognized the independence of Bosnia and Herzegovina ${ }^{53}$ which became a UN member in May 1992. The recognition of Bosnia and Herzegovina led to an internal, civil, and ethnic war. The interference of the sovereign states of Serbia and Croatia in the Bosnian War marked a struggle for territorial expansion. Hostilities began on April $6^{\text {th }}, 1992^{54}$ and lasted until October $1995^{55}$.

the Conference assessed that it had failed to resolve the Yugoslav state crisis. (Radomir Nešković, Nedovršena država - Politički sistem Bosne i Hercegovine, Friedrich-Ebert-Stiftung, Sarajevo, 2017. godine, pp. 123-125).

48 "Out of a population of 4.5 million, there were 600.000 Serbs". (Ibidem, p. 149).

${ }^{49}$ Especially its medieval Old Town which is designated as a UNESCO World Heritage Site.

${ }^{50}$ Ibidem, p. 150.

${ }^{51}$ An acronym for the "United Nations Protection Forces" founded on February $21^{\text {st }}, 1992$, with Resolution 743 of the Security Council. The withdrawal process was conducted between March and December 1995. The mission of the Blue Helmets included the territories of former Yugoslavia (except Slovenia) - parts of Croatia, Bosnia-Herzegovina, and Macedonia.

${ }^{52}$ Faris Gavrankapetanović, Uloga zdravstva u period opsade i odbrane Sarajeva, [in:] Opsada i odbrana Sarajeva 1992-1995, Sarajevo 2008, p. 275.

${ }^{53}$ Davor Marijan, Vještački nalaz: o ratnim vezama Hrvatske i Bosne i Hercegovine (1991-1995), Časopis za suvremenu povijest, 36/2., Zagreb 2004, p. 220.

${ }^{54}$ At its meeting in Luxembourg held on the same day, the Council of the European Union declared the adoption of a Declaration about Yugoslavia by which the independence of Bosnia and Herzegovina was recognized. (Slobodanka Kovačević, Bosna i Hercegovina - jezgro velikosrpskog projekta; Hronologija jugoslovenske krize 1942-1993., Institut za evropske studije, Beograd, 1994, p. 26.

${ }^{55}$ Balkan Battlegrounds: A Military History of the Yugoslav Conflict, 1990-1995, vol. I, Washington 2002, 390-392; The Dayton peace Agreement is the General Framework Agreement for Peace in Bosnia and Herzegovina signed in the Wright-Patterson Air Base in Dayton, Ohio, which effectively ended the War in Bosnia and Herzegovina (1992-1995). According to the Agreement, Bosnia and Herzegovina is a state composed of two 
The Bosniak-Croat war was finalized with the Washington Treaty on March $18^{\text {th }}$, $1994^{56}$.

The weakness and inability of the international forces were sealed with the occupation of the UN Protection Zone in Srebrenica during which the Serbian units led by Ratko Mladić murdered more than 8000 civilians $^{57}$. This crime was later known as the Genocide in Srebrenica. Attempts to conceal the traces of execution were made by transferring corpses from primary to secondary resting places. Through the Operation Oluja (English: Storm), Croatian forces regained sovereignty over territories lost to Croatian Serbs ${ }^{58}$. The War in Bosnia was ended with a trilateral agreement in Dayton on November $21^{\text {st }}$, $1995^{59}$. This agreement which ended the armed clashes was initiated by the American special envoy Richard Holbrooke and was signed by representatives of all three $\operatorname{sides}^{60}$.

The continuous distancing of official Belgrade from the Srebrenica Genocide, served as a pretext for the NATO alliance to conduct a military intervention and form a protectorate in Kosovo, which was finalized on June $9^{\text {th }}, 1999$ with the military agreement in $\mathrm{Ku}$ manovo ${ }^{61}$.

The International Criminal Tribunal for the former Yugoslavia was the first international criminal court which stated verdicts of genocide in Europe. In its case against Radislav Krstić, the Appeals Chamber of the Tribunal established that genocide was committed in Srebrenica in July 1995, after the city was captured by the forces of Bosnian Serbs $^{62}$. „The Trial Chamber of the International Criminal Court for Former Yugoslavia came to an irrefragable conclusion that the military forces of Bosnian Serbs murdered around seven and eight thousand males and youngsters of Bosnian Muslim ethnicity in July 1995; that the victims were civilians or prisoners of war; that the massacre and the later operations of concealment were planned and well-organized, and that this was a deed of genocide" 63 .

entities, the predominantly Serbian-populated Republika Srpska (49\% of the territory), and the Bosniak and Croat populated Federation of Bosnia and Herzegovina ( $51 \%$ of the territory). The main partakers of the Conference held between 1 and 25 of November 1995 were the former President of Republic of Serbia Slobodan Milošević, the President of the Presidency of the Republic of Bosnia and Herzegovina Alija Izetbegović, the President of the Republic of Croatia Franjo Tuđman, US representatives Warren Christopher (Secretary of State), the mediator Richard Holbroke and General Wesley Clark. The Agreement was signed in Paris on December 14 (Balkan Battlegrounds: A Military History of the Yugoslav Conflict, 1990-1995, vol. I, Washington 2002, pp. 390-392);

${ }^{56}$ Kasim Trnka, Konstitutivnost naroda, Vijeće Kongresa bošnjačkih intelektualaca, Sarajevo 2000, pp. $33-41$.

${ }^{57}$ Smail Čekić, Genocid i istina o genocidu u Bosni i Hercegovini, Institut za istraživanje zločina protiv čovječnosti i međunarodnog prava Univerziteta u Sarajevu, Sarajevo 2012, p. 25.

${ }^{58}$ Kosta Novaković, Srpska Krajina. Usponi, padovi uzdizanja, Srpsko kulturno društvo Zora, Beograd 2009 , p. 452.

${ }^{59}$ Srećko Latal, Agreement in its Labyrinth; The Legacy of Peace - Bosnia and Herzegovina 20 years after the Dayton Peace Accords, Friedrich-Ebert-Stiftung (FES) Sarajevo 2015, p. 23; Lívia Benková, The Dayton Agreement Then and Now; Fokus, 7/2016, Austria Institut für Europa und Sicherheitspolitik, Hainburg, Donau 2016., p. 1.

${ }^{60}$ Srećko Latal, Agreement ..., pp. 21-26.

${ }^{61}$ NATO: Military Technical Agreement https://www.nato.int/kosovo/docu/a990609a.htm

${ }^{62}$ Smail Čekić, Genocid i istina o genocidu u Bosni i Hercegovini ..., pp. 479-482.

${ }^{63}$ Međunarodni krivični sud za bivšu Jugoslaviju, Činjenice o Srebrenici, Outreach, 8. outreach@icty.org http://www.un.org.icty/index-b.html 
Thus began the process of the finalization of the Yugoslav conflict which was concluded with the separation of Montenegro (following a referendum) on May 21st, $2006^{64}$ and the declaration of independence by Kosovo on February 17th, $2008^{65}$.

This marked the definite end of the breakup of SFR Yugoslavia which was initiated by democratic revolutions in Poland and other countries under Soviet socialist influence back in the 1980s. The dissolution of the state of South Slavs - Yugoslavia, took a decade-long agony, although its periodically interrupted building lasted between 1918 and 1991.

\section{Conclusion}

Numerous historians, jurists, sociologists, and political scientists have different views on the history and the state-legal continuity of the two states - the Kingdom (1918-1943) and the Federation (1943-1991). While for the most it represents a history of a state devoid of a legitimate constitutional principle, for others it is a former socialist creation of the Yugoslav union, which perpetuated a cult of personality for decades. For Yugo-nostalgic cosmopolitans, it is an inimitable democratic socialist community of mixed religious and national structures that will never again occur in Europe. The fall of socialism mistakenly referred to as communism by quasi-science and opponents of Yugoslavia, created space for the integration of its secessionist republics into the world of Western liberal democracy, based on the models of a ruthless market economy. For many theorists of Yugoslav socialism, the sole engagement in the diversity of Europe's cultural heritage and structural specificities does not detract the very painful processes of bloody war transformation of Yugoslavia, which, as a member of numerous international organizations and alliances, has played a very important role in the politics of loosening international relations. The role of small socialist Yugoslavia in the community of the so-called "Third Bloc" - contributes to its position in the non-aligned, non-belligerent world.

Unlike Poland, the rule of Josip Broz Tito was inherited by republic oligarchies and collective ,presidency”that wasn't strong enough to hold the helm of „Posttitoism”. His vision of Yugoslavia, which he sublimated ideologically and military-politically, humanized and opened towards the world, was linked to the historically determined fate of socialism. This idea lost its touch with reality following his death on May 4th, 1980. Yugonostalgics believe that a multireligious and nationally heterogenous Yugoslavia would survive solely with the neutralization of federal borders, the introduction of Yugoslav nation, and language. The modus operandi of the actual political culture are the forced wars in the 90s and the vicious tradition of violence, as well as the attempts for a violent solution of the ongoing political and ethnic conflicts. The prisoner camps of Keraterm, Trnopolje, Omarska, and Manjača which took the lives and health of the citizens of the mutual Yugoslav Federation are proof of the domination of such methods.

${ }^{64}$ Ružica Mrdaković Cvetković, Međunarodni kontinuitet Srbije posle odvajanja Crne Gore; Biblio, Vol. LVIII, br. 3, 2006, p. 326.

${ }^{65}$ Branislav Radeljic, Kosovo 1998-2008: Human Rights from War to Independence: [in:] International Conference: Human Rights, Individualism and Globalization Bethany College, Bethany WV, USA, April 10-12, 2008, p. 13. 
The episode of separatism and demarcation between Yugoslav federal entities is one of the ugliest stages in Balkan history. Unexpectedly severe and bloody, these war conflicts were met with passivity among the international community which was preoccupied with its reintegration and unwillingness to penetrate the depths of the divisions between formerly fraternal Yugoslav peoples. The disappointed Yugoslav citizens consider the disintegration of their country to be a part of the series of conspiracies of European and global diplomacy. The most negative marks were given to the position and role of the Yugoslav People's Army - the unique defense force of the peoples and minority communities of the SFR Yugoslavia, which recognized Serbia and its narcissistic leader Slobodan Milošević as its backbone. The breakup of Yugoslavia left a stain on the face of Europe, which lacked the strength and willpower to prevent the genocide of Bosniak civilians in Srebrenica in July 1995, at the very end of its bloodiest century. It marked the beginning of the end of a country whose dissolution cost its citizens more than its foundation.

\section{Bibliography}

Ast S., Poljski sindikat 1980-2005: Solidarnost i melanholija, Vreme br. 765, Beograd, 1.9.2005.

Barić N., Srpska pobuna u Hrvatskoj: 1990.-1995., Zagreb, 2005.

Barker C., Revolutionary Rehearsals. London: Bookmarks, 1987.

Benková L., The Dayton Agreement Then and Now; FOKUS, 7/2016, Austria Institut für Europa und Sicherheitspolitik, Hainburg, Donau 2016.

Biberaj E., Shqipëria në tranzicion, Rruga e vështirë drejtë demokracisë 1990-2010, AIIS, Tiranë, 2011.

Čekić S., Genocid i istina o genocidu u Bosni i Hercegovini; Univerzitet u Sarajevu \& Institut za istraživanje zločina protiv čovječnosti i međunarodnog prava, Sarajevo 2012.

Gavrankapetanović F., Uloga zdravstva u period opsade i odbrane Sarajeva, Opsada i odbrana Sarajeva 1992-1995, Sarajevo 2008.

Izvješce Centralne komisije o provođenju izjašnjavanja u Jugoslaviji o autonomiji srpskog naroda u Republici Hrvatskoj, 30.9.1990, [in:] Dokumenti, knj. 2, ed. Mate Rupić, Hrvatski memorijalno-dokumentacijski centar Domovinskog rata, Slavonski Brod 2007.

Jović D., Jugoslavija država koja je odumrla, Prometej, Zagreb 2003.

Klein N., Doktrina šoka: uspon kapitalizma katastrofe. Zagreb: V.B.Z., 2008.

Kovačević S., Bosna i Hercegovina - jezgro velikosrpskog projekta, Hronologija jugoslovenske krize 1942-1993., Institut za evropske studije, Beograd 1994.

Kroford K., 1989. - Godina preokreta ne samo za Nemce, [in:] Konsolidacija demokratije 20 godina nakon pada Berlinskog zida, eds. I. Vujačić, Č. Čupić, B. Vranić, Beograd 2009.

Latal S., Agreement in its Labyrinth, [in:] The Legacy of Peace - Bosnia and Herzegovina 20 years after the Dayton Peace Accords, Friedrich-Ebert-Stiftung (FES) Sarajevo 2015.

Malkolm N., Kosovo - Kratka povijest, Sarajevo 2000.

Marijan D., Vještački nalaz: o ratnim vezama Hrvatske i Bosne i Hercegovine (1991-1995), Časopis za suvremenu povijest, 36/2., Zagreb 2004.

Marković, Ante. Hrvatska enciklopedija, mrežno izdanje. Leksikografski zavod Miroslav Krleža, 2020, http://www.enciklopedija.hr/Natuknica.aspx?ID=39021 (access 24.04.2020).

Michnik A., Wasz Prezydent, Nasz Premier, „Gazeta Wyborcza”, nr 40, 03/07/1989.

Milišić S., Genocid: Pripreme i poricanje. Uvod u realizovanje genocida i zatvaranje kruga genocida, Ljudska prava, 1-4, Sarajevo 2008. 
Mrdaković-Cvetković R., Međunarodni kontinuitet Srbije posle odvajanja Crne Gore; Biblio, Vol. LVIII, br. 3, 2006.

Musić G., Suprotstavljene interpretacije tranzicije: [in:] Balkan i Srednja Evropa-Izgubljeno u Tranziciji: Kritička Analiza Procesa Društvene Transformacije, Rosa Luxemburg Stiftung, Beograd 2011.

NATO: Military Technical Agreement, https://www.nato.int/kosovo/docu/a990609a.htm

Nešković R., Nedovršena država - Politički sistem Bosne i Hercegovine, Sarajevo 2017.

Novaković K., Srpska Krajina, Usponi, padovi uzdizanja; Srpsko kulturno društvo Zora, Beograd 2009.

Ost D., The Defeat of Solidarity: Anger and Politics in Postcommunist Europe. Ithaca, N.Y.: Cornell University Press, 2005.

Paczkowski A., Pola stoljeća povijesti Poljske: 1939-1989 godine, Zagreb: Profil, 2001.

Pauković D., Posljednji kongres Saveza komunista Jugoslavije: uzroci, tijek i posljedice raspada, „Suvremene teme-contemporary issues”, Vol. 1, No. 1, Political Science research centre, Zagreb 2008.

Petranović B., Istorija Jugoslavije 1918-1988, t. III „Socijalistička Jugoslavija 1945-1988”, Nolit, Beograd 1988.

Podgornik B., Protest pod zemljom, „Vjesnik”, Zagreb, 21.02.1989.

Radeljic B., Kosovo 1998-2008: Human Rights from War to Independence: in: International Conference: Human Rights, Individualism and Globalization Bethany College, Bethany WV, USA, April 10-12, 2008.

Radojević L. K., Podvršič A., Slovenačka omladina i neoliberalizacija Jugoslavije: od alternativnih pokreta do liberalnog trećeg bloka, [in:] Gradove smo vam podigli: o protivrečnostima jugoslovenskog socijalizma, Centar CZKD - Centar za kulturnu dekontaminaciju, Beograd 2018.

Rat u Sloveniji - Dokumenta Predsedništva SFRJ 1991, tom II (jun - jul 1991), eds. K. Nikolić, V. Petrović, Institut za savremenu istoriju \& Fond za humanitarno pravo, Beograd 2012.

Republika Hrvatska i Domovinski rat 1990.-1995. Dokumenti - Dokumenti institucija pobunjenih Srba u Republici Hrvatskoj (1990-1991), [in:] Dokumenti, knj. 2, ed. Mate Rupić, Hrvatski memorijalno-dokumentacijski centar Domovinskog rata, Slavonski Brod 2007.

Samardžić N., Drugi dvadeseti vek, „Službeni glasnik”, Beograd 2008.

Savezno izvršno veće - Sekretarijat za informacje. Program daljih reformi jugoslovenskog društva - vreme promena, Beograd 1990.

Silber L., Little A, Smrt Jugoslavije, Co Libri, Rijeka - Opatija 1996.

Služben vesnik na Rep. Makedonija, 43/1991, Skoplje 1991.

Srpsko nacionalno vijeće proglašava autonomiju srpskog naroda u Hrvatskoj, 30.9.1990, [in:] Dokumenti, knj. 2, ed. Mate Rupić, Hrvatski memorijalno-dokumentacijski centar Domovinskog rata, Slavonski Brod 2007.

Trnka K., Konstitutivnost naroda, Vijeće Kongresa bošnjačkih intelektualaca, Sarajevo 2000.

Vasić M., Cerović S., Ćirić A., Krvava odbrana vlasti, „Vreme” 11.03.1991, Beograd.

Vodič za unutrašnji dijalog - Kosovska hronologija 1974-2017, Beograd, Septembar 2017.

Vučetić R., Vreme kada je narod govorio. Dokumenti o prošlosti: Politika, 1988-1991. (Odjeci i reagovanja - Okrugli sto), Fond za humanitarno pravo, Beograd, 14-15. decembar 2001.

Wnuk-Lipiński E., Teorijska zapažanja o procesu transformacije u Poljskoj, „Republika”, God. XV, br. 1-31. jul 2003.

Zimerman V., Poreklo jedne katastrofe. Jugoslavija i njeni rušitelji, Beograd 1996. 
Redžep Škrijelj - turkolog, pisarz i publicysta, dr na stanowisku docenta, pracownik naukowy i dydaktyczny Państwowego Uniwersytetu w Nowym Pazarze. Jego zainteresowania naukowe koncentruja się wokół kultury muzułmańskiej grup narodowych i etnicznych w byłej Jugosławii, szczególnie w Bośni i Hercegowinie oraz w Macedonii. Jest autorem m.in. następujących prac: Problem kulturnog identiteta sandžačkih Bošnjaka, Godišnjak BKZ „Preporod”, god. XIII, Sarajevo 2013, 275-286; Kulturna emancipacija muslimanke u Kraljevini i socijalističkoj Jugoslaviji (1929-1992), Interkulturalnost (Časopis za podsticanje i afirmaciju interkulturalne komunikacije), br. 9, Novi Sad, mart 2015, 41-51; Makedonya'daki Boşnaklarin En Eski Aniti: Kral Kizi Türbesi (Most Prominent Cultural Landmarks of the Bosnians in Macedonia: The Mausoleum Of Bosnian Princess Katarina), Osmanlý Mirasý Arațtýrmalarý Dergisi / Journal of Ottoman Legacy Studies, Cilt 4, Sayý 10, Kasým 2017 / Volume 4, Issue 10, November 2017, 145-151. 